\title{
Studi kelayakan proses pembubutan penekan kopling sepeda motor dengan mesin boxford cnc menggunakan pendekatan statistical process control
}

\section{GNK. Yudhyadi*, M. Wijana, I Ketut Sedana Yasa, I Made Adi Sayoga}

Teknik Mesin Fakultas Teknik Universitas Mataram, Jln. Majapahit No. 62 Mataram Nusa Tenggara Barat Kode Pos : 83125, Telp. (0370) 636087; 636126; ext 128 Fax (0370) 636087.

*Email: ik_yadhy@hotmail.com

\section{ARTICLE INFO}

Article History:

Received 13 Februari 2017

Accepted 20 March 2017

Available online 30 June 2017

Keywords:

Product quality

Statistical process control

CNC turning

Competitiveness

\section{ABSTRACT}

Now days, a company has been experiencing and facing a tight competitive siege. To be surviving within this competition, the company must be creative in developing new and robust ideas to improve their business competitiveness which differentiate them from the others. The product quality was the main issues among others. The quality of a product that offered to the consumers must be cheap and have met with consumer satisfaction. Exploring these ideas, current research has conducted with the main goal was investigating the quality of product produced on CNC Turning. The quality was calculated with a Statistical Process Control (SPC) analysis. Meanwhile, ductile iron workpieces size of $130 \mathrm{~mm}$ in length and $19 \mathrm{~mm}$ in diameter were manufactured for the samples. The data gathered including diameter, length, and thickness of the samples measured with Digital Vernier Caliper and Micrometer. Based on data observed, the result of experiment shows that the quality of sample products produced in single run (12 products) has met with basic standard requirement with which all samples dimension was lay inside the control limit (Upper and Lower Control Limit (UCL and LCL). It can be concluded that each variable still in process control and was ready for the automation.

\section{PENDAHULUAN}

Secara konseptual, produk merupakan pemahaman subyektif dari produsen atas sesuatu yang bisa ditawarkan sebagai usaha untuk mencapai tujuan organisasi melalui pemenuhan atas keinginan konsumen. Produk sendiri merupakan hasil kerja yang dapat ditawarkan ke pasar untuk mendapatkan perhatian, dibeli, digunakan, atau dikonsumsi yang dapat memuaskan keinginan atau kebutuhan (Kotler, 2009). Produk merupakan kunci dalam keseluruhan penawaran pasar (Kotler and Keller, 2012) dan merupakan persepsi konsumen yang dijabarkan oleh produsen melalui hasil produksinya (Tjiptono dan Fandy, 2008). Sebagai konsekuensi, untuk dapat diterima oleh konsumen, setiap produk yang dihasilkan produsen harus memenuhi kriteria kualitas yang diinginkan 
(conformance to customer satisfaction) (Garvin, 1988).

Kualitas dari sebuah produk merupakan gambaran tentang kemampuan suatu produk untuk memberikan fungsinya yang meliputi daya tahan keandalan, kemudahan operasi dan perbaikan, serta atribut bernilai lainnya. Kualitas merupakan keunggulan yang dimiliki suatu produk dan membedakannya dengan produk lain (Kotler \& Armstrong, 2008; Alma, 2011), dan biasanya kemampuan tersebut dinyatakan secara tersirat (Kotler, 2009; Crosby, 1979), dan merupakan perpaduan antara sifat dan karakteristik yang menentukan sejauh mana dapat memenuhi kebutuhan pelanggan (Tjiptono dan Fandy, 2008; Demin, 1982). Dari hal tersebut, dapat disimpukan bahwa kualitas suatu produk dihasilkan melalui suatu tahapan tertentu dengan mempertimbangkan kelebihan dan kekurangannya dan disesuaikan dengan kebutuhan konsumen. Kualitas yang baik dapat meningkatkan kepuasan pelanggan dimana perusahaan memaksimalkan pengalaman pelanggan yang menyenangkan dan meminimalkan pengalaman pelanggan yang kurang menyenangkan (Atmawati dan Wahyudin, 2007).

Perkembangan teknologi dan kompetisi proses manufaktur, menyebabkan peningkatan kebutuhan akan kualitas produk yang tinggi (high quality product) yang dihasilkan dengan kecepatan produksi yang tinggi (high speed manufacturing). Dalam meningkatkan dan mengotomatisasikan proses pengembangan dan perencanaan sebuah produk, dewasa ini, produsen sudah menerapkan penggabungan sistem mekanik, elektronik, kontrol dan pemrograman computer yang sering dikenal dengan istilah Concurrent Engineering (CE).
Dimana, menurut U.S. Institute of Defense, Concurrent Engineering merupakan suatu pendekatan sistematis terhadap desain produk dan proses yang terkait secara bersamaan dan terintegrasi, termasuk di dalamnya manufacturing dan pendukung lainnya dengan bantuan sistem CAD (Computer Aided Design) /CAM (Computer Aided Manufacture). Dengan dukungan mesin CNC (computer numerically controlled machine) dalam Concurrent Engineering program yang dibuat dengan CAD/CAM dapat langsung diproduksi berkali-kali dengan akurasi yang tepat (Krar and Gill, 1999)

Pengendalian kualitas produk sangat diperlukan dalam menjaga daya saing dari perusahaan. Pengendalian kualitas produk dimaksudkan agar spesifikasi produk yang telah ditetapkan dapat tercermin dalam produk akhir. Adapun faktor-faktor yang mempengaruhi tingkat pengendalian kualitaas produk adalah kemampuan proses, spesifikasi, jumlah diluar spesifikasi dan efisiensi produksi (Assauri, 2004). Statistical Process Control (SPC) merupakan salah satu metode yang digunakan dalam mengontrol kualitas proses permesinan. SPC akan sangat membantu untuk melihat variabilitas dari produk yang dihasilkan termasuk dimensinya dan jumlah kesalahan (defect).

Berdasarkan pemaparan di atas, yang menjadi tujuan utama dari studi ini adalah untuk melihat secara komprehensip keandalan mesin CNC Turning BoxFord 250PCi terhadap kualitas produk "Penekan Kopling sepeda motor" dengan menggunakan pendekatan Statistical Process Control (SPC) teknik dalam satu kali rangkaian proses (one single run production).

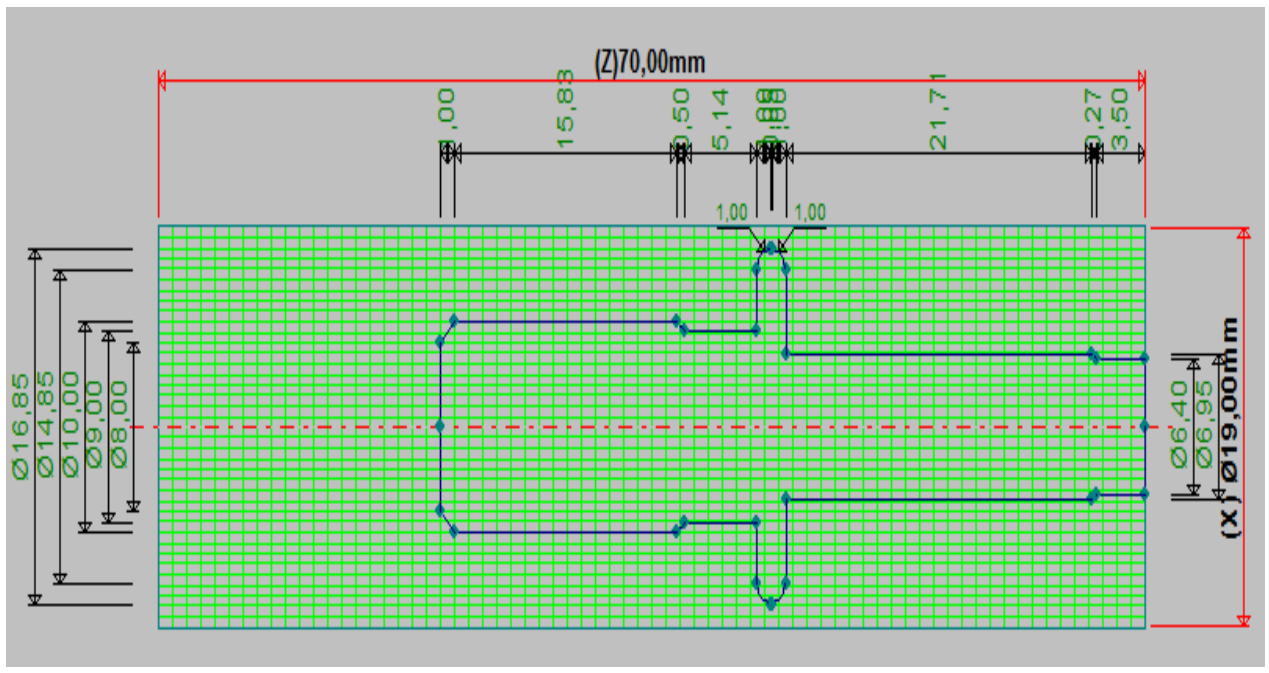

Gambar 1. Gambar Penekan Kopling yang diproduksi 


\section{METODE PENELITIAN \\ Gambar Produk}

Gambar produk yang akan dibahas dalam penelitian ini adalah seperti terlihat pada gambar 1, yang dihasilkan dengan menggunakan progam Computer Aidded Design (CAD) Boxford.

\section{Teknik Pengambilan Data}

Data yang digunakan dalam penelitian ini merupakan data-data hasil dari proses eksperimen mengenai prameter yang diuji, di mana hasil data penelitian yang didapatkan diambil dari bagian produk seperti terlihat dalam gambar 2 .

\section{Teknik Pengolahan Data}

Dalam penelitian ini digunakan analisis Statistical Process Control (SPC), untuk menyelidiki variabilitas proses dan tindakan pembetulan yang harus dilakukan sebelum terlalu banyak produk yang tidak sesuai dengan standar produk yang diinginkan (defect).

\section{HASIL DAN PEMBAHASAN \\ Data Observasi}

Dari hasil pembubutan yang telah dilakukan, langkah selanjutnya mengukur semua peroduk dengan menggunakan alat ukur Digital Vernier Calipperl. Urutan pengukuran diameter yang diuji kualitasnya terlihat dalam gambar $3(A)$ dan dimensi linier panjang ditunjukkan dalam gambar 3(B). Sedangkan data hasil pengukurun ditampilkan dalam table 1 dan tabel 2.

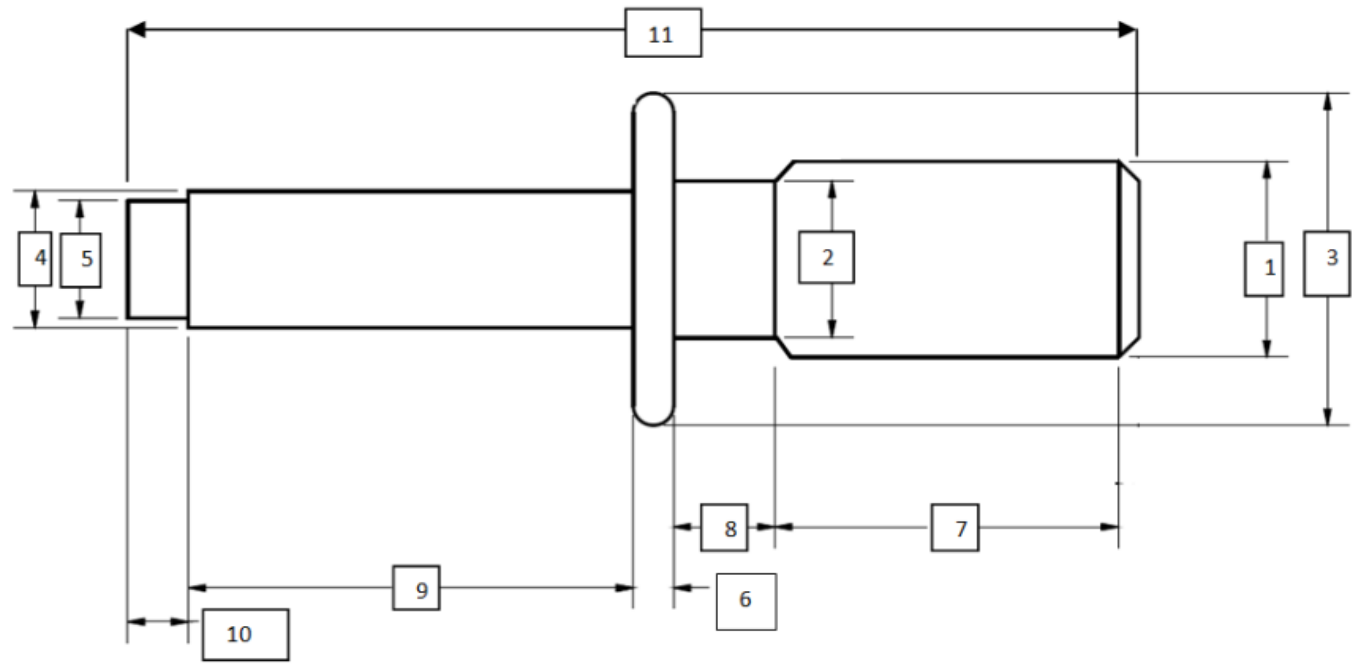

Keterangan :

1. Pengukuran Diameter $1=10,00 \mathrm{~mm}$

2. Pengukuran Diameter $2=9,00 \mathrm{~mm}$

3. Pengukuran Diameter $3=16,85 \mathrm{~m}$

4. Pengukuran Diameter $4=6,95 \mathrm{~mm}$

5. Pengukuran Diameter $5=6,40 \mathrm{~mm}$

6. Pengukuran ketebalan $3=2,05 \mathrm{~mm}$

7. Pengukuran Panjang $1=17,45 \mathrm{~mm}$

8. Pengukuran Panjang $2=5,14 \mathrm{~mm}$

9. Pengukuran Panjang $3=21,71 \mathrm{~mm}$

10. Pengukuran Panjang $4=3,50 \mathrm{~mm}$

11. Pengukuran Panjang $5=50,00 \mathrm{~mm}$

Gambar 2. Dimensi hasil produk yang diukur 
Tabel 1. Data Hasil Pengukuran Dimensi Diameter Produk

\begin{tabular}{cccccc}
\hline \multirow{2}{*}{ No. Observasi } & \multicolumn{5}{c}{ Nomor Identitas Diameter } \\
\cline { 2 - 6 } & 1 & 2 & 3 & 4 & 5 \\
\hline 1 & 10.02 & 8.95 & 16.77 & 6.89 & 6.35 \\
2 & 10.06 & 8.95 & 16.79 & 6.93 & 6.36 \\
3 & 10.05 & 8.96 & 16.78 & 6.93 & 6.35 \\
4 & 10.07 & 8.96 & 16.83 & 6.93 & 6.38 \\
5 & 10.04 & 8.95 & 16.78 & 7.51 & 6.37 \\
6 & 10.07 & 8.96 & 16.73 & 6.93 & 6.41 \\
7 & 10.08 & 8.95 & 16.83 & 6.91 & 6.39 \\
8 & 10.07 & 8.96 & 16.77 & 6.94 & 6.37 \\
9 & 10.09 & 8.97 & 16.81 & 6.94 & 6.39 \\
10 & 10.13 & 8.98 & 16.80 & 6.97 & 6.46 \\
11 & 10.13 & 8.99 & 16.88 & 6.98 & 6.43 \\
12 & 10.15 & 8.99 & 16.92 & 7.00 & 6.46 \\
13 & 10.15 & 8.99 & 16.91 & 7.00 & 6.45 \\
14 & 10.16 & 9.00 & 16.87 & 7.00 & 6.45 \\
15 & 10.16 & 9.00 & 16.87 & 6.99 & 6.45 \\
\hline
\end{tabular}

Tabel 2. Data Hasil Pengukuran Dimensi Linier Panjang Produk

\begin{tabular}{ccccccc}
\hline No. Obser & \multicolumn{7}{c}{ Nomor Identitas Panjang } \\
\cline { 2 - 7 } vasi & 1 & 2 & 3 & 4 & 5 & 6 \\
\hline 1 & 17.66 & 4.93 & 21.51 & 3.22 & 50.16 & 2.14 \\
2 & 17.64 & 4.97 & 21.63 & 3.26 & 50.17 & 2.17 \\
3 & 17.44 & 4.59 & 21.58 & 3.36 & 49.87 & 2.17 \\
4 & 17.59 & 4.60 & 21.61 & 3.06 & 50.06 & 2.23 \\
5 & 17.52 & 5.00 & 21.65 & 3.15 & 50.06 & 2.14 \\
6 & 17.61 & 4.54 & 21.73 & 3.34 & 50.24 & 2.14 \\
7 & 17.66 & 4.96 & 21.68 & 3.28 & 49.97 & 2.19 \\
8 & 17.63 & 5.02 & 21.63 & 3.16 & 50.00 & 2.18 \\
9 & 17.64 & 4.92 & 21.65 & 3.18 & 49.86 & 2.20 \\
10 & 17.70 & 4.89 & 21.76 & 3.29 & 50.22 & 2.20 \\
11 & 17.67 & 5.17 & 21.54 & 3.48 & 50.50 & 2.33 \\
12 & 17.73 & 4.82 & 21.72 & 3.48 & 50.46 & 2.30 \\
13 & 17.70 & 5.10 & 21.56 & 3.15 & 50.37 & 2.57 \\
14 & 17.61 & 5.12 & 21.71 & 3.30 & 50.51 & 2.45 \\
15 & 17.69 & 4.97 & 21.69 & 3.10 & 50.34 & 2.47 \\
\hline
\end{tabular}

\section{Pengolahan Data dan Pembahasan}

\section{Uji Kualitas Dimensi Diameter Produk}

Berdasarkan pada data hasil pengukuran yang tercantum dalam tabel 1 didapatkan grafik hasil pengolahan data ke 5 diameter yang diamati dengan menggunakan Analisis Statistical Process Control (SPC) seperti ditampilkan berturut-turut dalam gambar $4(A, B, C, D, E)$.

Dari gambar hasil analisis kualitas produk, ditinjau dari dimensi diameter yang diperlihatkan dalam grapik SPC, terlihat bahwa seluruh dimensi produk masih dalam kontrol kendali ( antara garis UCL dan LCL). Batas Kendali Atas/Upper Limit Control (UCL) untuk diameter 1, 2, 3, 4 dan 5 berturut-turut sebesar 10,14; 9,05; 16,99; 7,05 dan $6,52 \mathrm{~mm}$, sedangkan Garis Tengah/Center Line (CL) masing-masing 10,$09 ; 8,98 ; 16,82 ; 6,95$ dan $6,40 \mathrm{~mm}$. Sementara itu batas Kendali Bawah/Lower Control Limit (LCL) adalah 9,95; 8,$90 ; 16,65 ; 6,84$ dan $6,28 \mathrm{~mm}$ untuk masingmasing diameter $1,2,3,4$, dan 5 . Dari hal tersebut, dapat disimpulkan bahwa seluruh data observasi terletak diantara batas UCL dan LCL. Dengan kata lain, proses pembuatan produk masih berada dalam kendali. Sehingga $H_{2}$ yang menyatakan proses pembuatan produk menggunakan Mesin CNC Turning BoxFord 
250PCi terkendali secara Statistik diterima dan $H_{1}$ dit

(A)
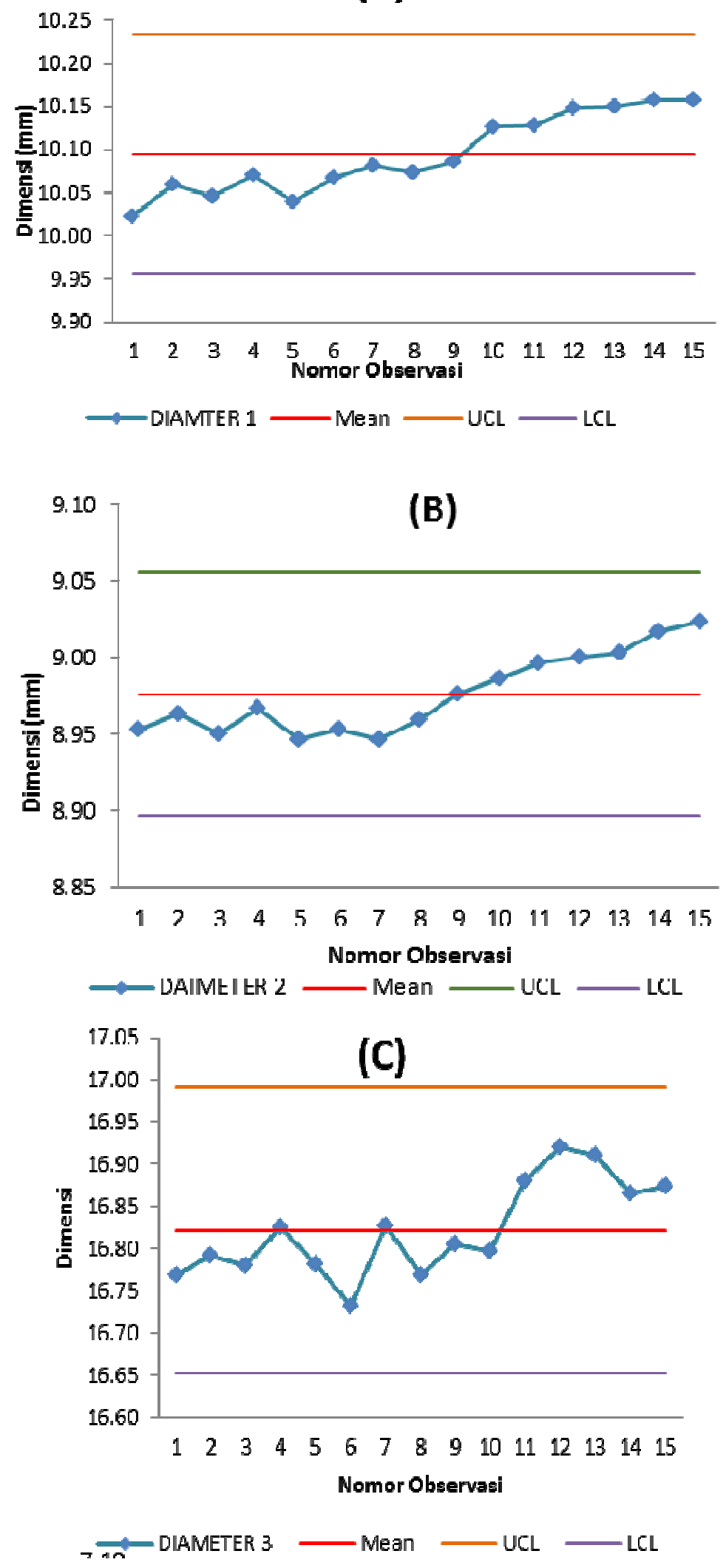

https://doi.org/10.29303/dtm.v7i1.4 

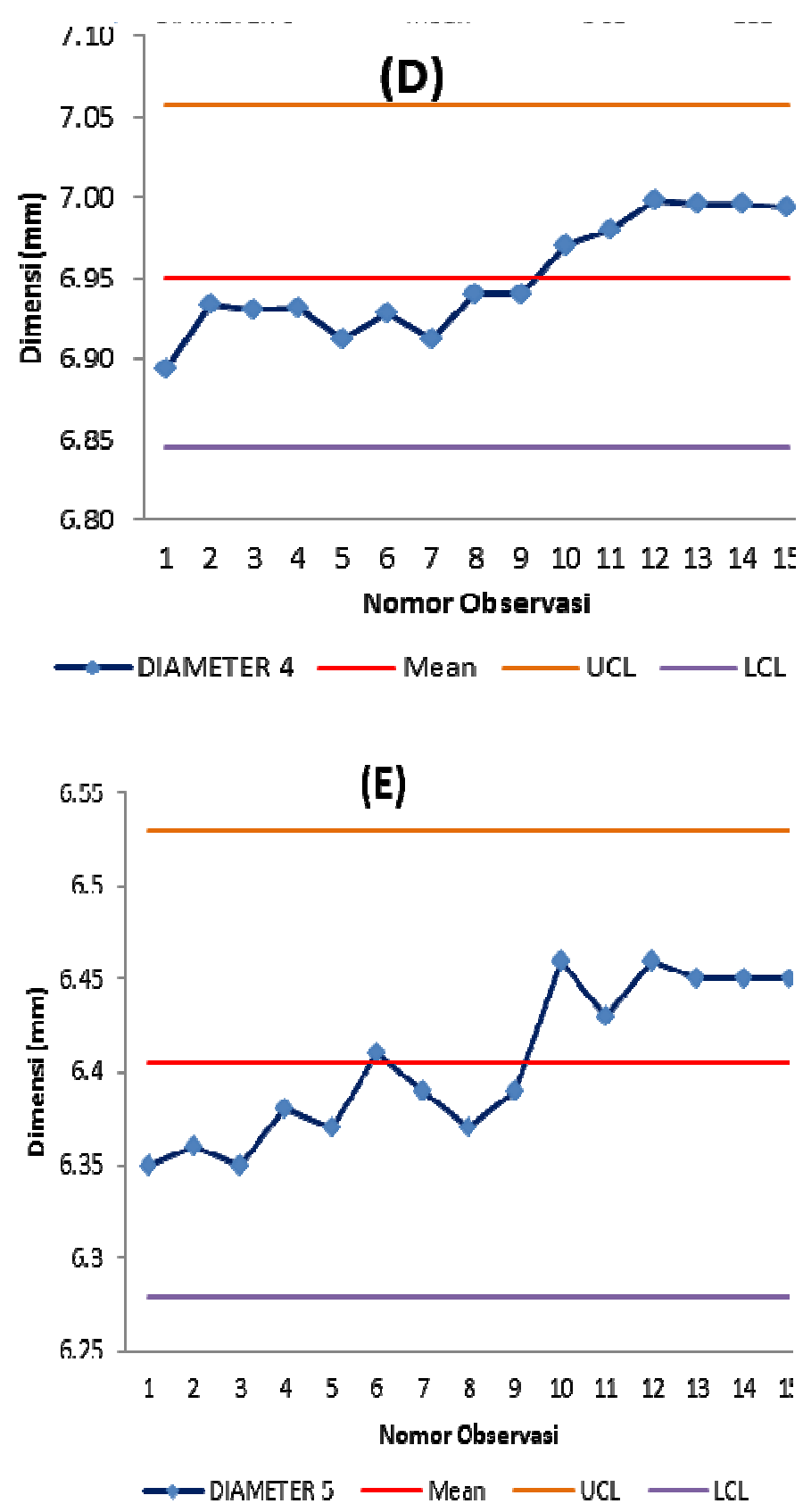

Gambar 4. Diagram kontrol individual untuk masing-masing diameter yang diteliti; (A) diameter 1; (B) diameter 2; (C) diameter 3; (D) diameter 4; (E) diameter 5 

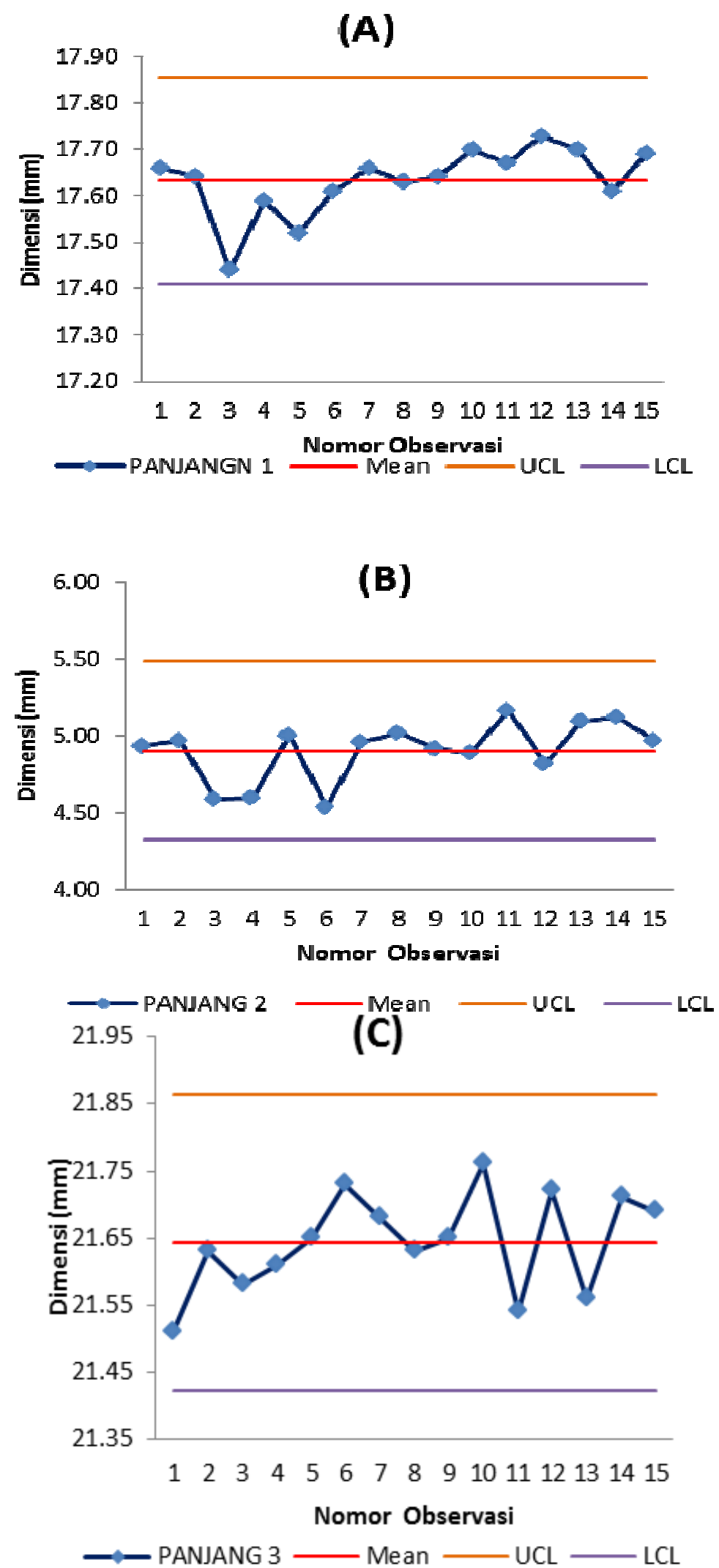

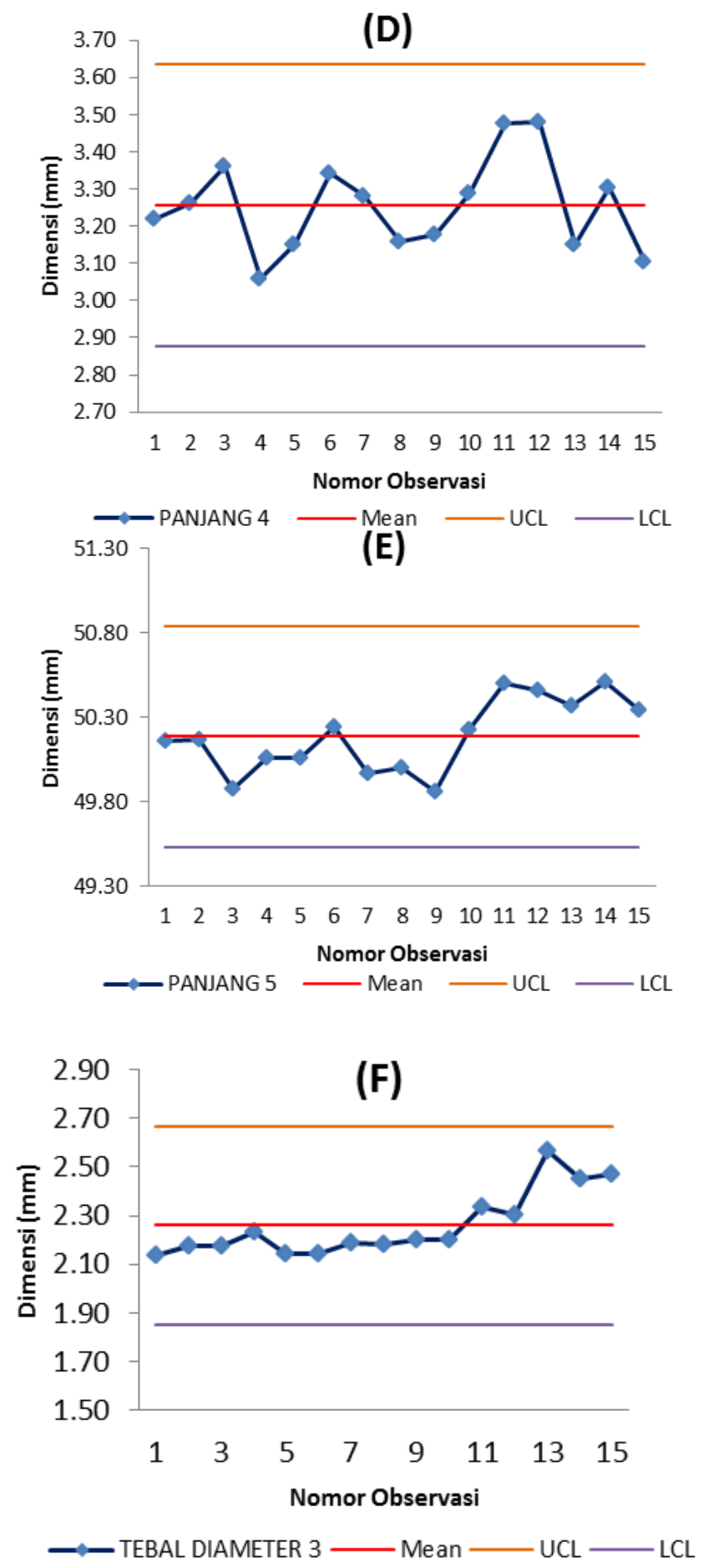

Gambar 5. Diagram kontrol individual untuk masing - masing dimensi linier panjang yang diteliti; (A) panjang 1; (B) panjang 2; (C) panjang 3; (D) panjang 4; (E) panjang 5; (F). panjang 6 


\section{Uji Kualitas Dimensi Linier Panjang Produk}

Berdasarkan data tabel 2 dan hasil pengolahan data menggunakan analisis Statistical Process Control (SPC), maka dapat dilihat hasilnya dalam diagram kontrol seperti ditunjukkan pada Gambar 5 (A, B, C, D, E, F).

Dari gambar 5 , hasil analisis kualitas produk ditinjau dari dimensi panjang (linier) yang diperlihatkan dalam grapik SPC (Gambar 5), terlihat bahwa seluruh dimensi produk masih dalam control kendali ( antara garis UCL dan LCL). Batas Kendali Atas/Upper Limit Control (UCL) untuk diameter 1, 2, 3, 4, 5 dan 6 berturut-turut sebesar 17,$65 ; 5,48 ; 21,86 ; 3,64 ; 50,84$ dan 2,66 $\mathrm{mm}$, sedangkan Garis Tengah/Center Line (CL) masing-masing 17,$63 ; 4,91 ; 21,64 ; 3,25 ; 50,19$ dan 2,26 mm. Sementara itu batas Kendali Bawah/Lower Control Limit (LCL) adalah 17,41; 4,33; 21,42; 2,88; 49,53 dan 1,85 mm untuk masing-masing diameter 1, 2, 3, 4, 5 dan 6. Dari hal tersebut, dapat disimpulkan bahwa seluruh data observasi terletak diantara batas UCL dan LCL. Dengan kata lain, proses pembuatan produk masih berada dalam kendali. Sehingga $H_{0}$ yang menyatakan proses pembuatan produk menggunakan Mesin CNC Turning BoxFord 250PCi terkendali secara Statistik diterima dan $H_{1}$ ditolak.

Berdasarkan pengolahan data yang telah dilakukan, dan peta control yang telah dibuat (Gambar 4 dan 5), terlihat bahwa tidak ada proporsi rijek (defect) dari produk yang dibuat. Data hasil observasi memperlihatkan bahwa semua data terdistribusi di sekitar garis Centre Line $(C L)$ dan tidak satupun ada data yang diluar Control limit berurutan. Variabilitas atau sebaran nilai dimensi baik diameter maupun panjang yang terjadi masih dalam batas yang diijinkan dan semata-mata disebabkan oleh variabilitas dari sifat fisis dan mekanis bahan baku. Sebaliknya tidak ada variabilitas yang disebabkan adanya kesalahan dalam pemilihan variabel proses pembubutan atau operator mesin. Dari hal tersebut, dapat disimpulkan bahwa semua parameter proses sudah sangat baik dan proses dapat dilanjutkan dan siap untuk digunakan dalam produksi masal.

\section{KESIMPULAN}

Dari hasil analisis kualitas produk hasil pengerjaan CNC Turning BoxFord 250PCi dengan menggunakan Statistical Process Control (SPC), dengan taraf signifikansi $(\alpha)=0,025$ dapat disimpulkan bahwa proses pembuatan sebanyak 15 produk, menggunakan metode Single Runing Process terkendali secara statistik ( $\mathrm{H} 0)$ diterima dan $(\mathrm{H} 1)$ ditolak. Hal ini dapat terlihat karena seluruh data observasi terletak di antara batas kendali baik Upper Limit Control (UCL) dan Lower Limit Control (LCL). Selanjutnya, ada sedikit variabilitas yang muncul yang disebabkan oleh variabilitas dari kekuatan bahan baku yang digunakan dan bukan disebabkan variabilitas atau kesalahan dalam pemilihan variabel proses permesinan. Selanjutnya, proses tersebut sudah dapat dikatakan memenuhi semua parameter untuk digunakan dalam produksi masal.

\section{UCAPAN TERIMAKASIH}

Penulis pada kesempatan ini mengucakan terimakasih kepada semua pihak yang membantu baik berupa materi maupun pikiran sehingga penelitian dan paper ini dapat terselesaikan. Yang ke dua penulis mengapresiasi Jurusan Teknik Mesin atas fasilitas yang dipergunakan dalam penelitian ini.

\section{DAFTAR PUSTAKA}

Alma B., 2011, Manajemen pemasaran dan pemasaran jasa, Alfabeta, Bandung

Assauri S., 2004, Manajemen produksi dan operasi, FE-UI, Jakarta.

Atmawati R., Wahyudin M., 2007, Analisis pengaruh kualitas pelayanan terhadap kepuasan konsumen pada matahari departement store di Solo Grand Mall, Jurnal Ekonomi dan Bisnis, 1-12.

Crosby P.B., 1979, Quality is free: The art of marketing quality certain, McGraw-Hill, New York.

Demin W.E., 1982, Out of the criisis-quality, productivity and competitive position, Cambridge University Press.

Garvin D., 1988, Managingn quality, The New York Press.

Kotler P., 2009, Marketing management, Pearson Prentice Hall.

Kotler P., Armstrong G., 2008, Prinsip-prinsip pemasaran, 12th edn, Erlangga, Jakarta.

Kotler P., Keller K., 2012, Marketing management, 14th edn, Pearson.

Krar S., Gill A., 1999, Computer numerical control programming basic, Industrial Press Inc., New York.

Tjiptono, Fandy, 2008, Strategi pemasaran, 3rd edn, ANDI Ofset, Yogyakarta. 